\title{
Effect of Macerated Tomato (Lycopersicon esculentum) and Carrot (Daucus carota) Oils on Hematological Parameters of Rainbow Trout (Oncorhynchus mykiss) at High Stocking Density
}

\author{
Başar Altınterim ${ }^{1}$, Önder Aksu ${ }^{2}$ \\ ${ }^{1}$ Turgut Özal University, Fisheries Faculty, Malatya, Turkey \\ ${ }^{2}$ Munzur University, Fisheries Faculty, Tunceli, Turkey \\ *basaraltinterim@gmail.com $\mathrm{D}$, onderaksu@munzur.edu.tr $\mathrm{iD}$ \\ Received date: 06.11.2019, Accepted date: 30.12.2019
}

\begin{abstract}
In this study, $2 \%$ of macerated tomato (Lycopersicon esculentum) and carrot (Daucus carota) oils were added to the feeds of rainbow trout with an average weight of $35.88 \pm 1.97 \mathrm{~g}$. The experiment was continued for 21 days and the samples were also measured for changes in the hematological parameters. Statistically, significant differences were found in LYM, RBC, HGB, HCT, MCH and NBT values $(\mathrm{p}<0.05)$. There was no statistically significant difference other blood parameters levels $(\mathrm{p}>0.05)$. It was determined that both macerated carrot and macerated tomato oils stimulated to the non-specific immune system and erythropoiesis at high stocking density. Especially, it was occurred that macerated carrot oil (MCO) more effective than macerated tomato oil (MTO).
\end{abstract}

Keywords: Blood parameters, carrot oil, NBT, tomato oil, trout

\section{Masere Domates (Lycopersicon esculentum) ve Havuç (Daucus carota) Yağlarının Yüksek Yoğunlukta Stoklanmış Gökkuşağı Alabalığı (Oncorhynchus mykiss, L.)'nın Hematolojik Parametrelerine Etkisi}

$\ddot{O} z$

$\mathrm{Bu}$ çalışmada, ortalama 35,88 $\pm 1,97 \mathrm{~g}$ ağırlığındaki gökkuşağı alabalıklarının yemlerine \%2 oranında masere domates (Lycopersicon esculentum) ve havuç (Daucus carota) yağları eklenmiştir. Deney 21 gün sürdürüldü ve hematolojik parametrelerdeki değişiklikler ölçüldü. İstatistiksel olarak lenfosit (LYM), eritrosit (RBC), hemoglobin (HGB), hematokrit (HCT), Hücre hemoglobini ortalaması MCH ve Nitroblue tetrazolium (NBT) değerlerinde anlamlı fark bulundu ( $\mathrm{p}<0,05)$. Diğer kan parametrelerinde ise istatistiksel olarak anlamlı bir fark bulunmadı $(\mathrm{p}>0,05)$. Yüksek yoğunlukta stoklamada hem masere havuç hem de masere domates yağlarının, spesifik olmayan bağışıklık sistemini ve eritropoeziyi uyardığı tespit edildi. Özellikle, masere havuç yağının (MCO) masere domates yağından (MTO) daha etkili olduğu görülmüştür.

Anahtar Kelimeler: Kan parametreleri, havuç yağı, NBT, domates yağı, alabalık

\section{INTRODUCTION}

High stock density is a chronic stress factor in fish (Braun et al., 2010). Blood parameters provide information about the health status of fish. Tomato (lycopene), carrot ( $\beta$-carotene) are rich in nutrients. Tomato consumption is reduced cancer risk (Giovannucci, 1999). It is determined that lycopene is a very useful compound in health for both animals and humans. Lycopene in tomato is a strong antioxidant (Rao and Agarwal, 1999). In addition, tomato contains vitamins, flavonoids, trace elements, phytostreols which are useful for health (Beecher, 1998; Raym and Rao, 2006).

Lycopene is twice as strong as $\beta$-carotene in neutralizing superoxide radical (Di Mascio et al., 1989; Palozza et al., 2012). Lycopene plays an vital role in the treatment of chronic diseases such as cardiovascular diseases (Kobayashi et al., 1996), immune system disorders, degenerative diseases and hormonal disorders. (Meydani et al., 1995; Aust et al., 2003).

Carotenoids are essential elements for fish diets. Fish have to take carotenoids than food such 
as algae, crustaceans etc. (Wozniake, 1996). Effects of carotenoids on aquatic animals are determined that increase resistance to diseases (Jha et al., 2007).

Fish contain a lot of carotenoids such as tunaxanthin (yellow), lutein (greenish-yellow), etc. Body of fish has the capacity to convert one form of carotenoid into another carotenoid. Dietary carotenoids can improve the fillet of fish that is increased value of fish. $\beta$-carotene extract is expensive and it can damage to the environment (Gupta et al., 2007). Plant carotenoids are cheap and affordable as an alternative to extracted carotenoids. $\beta$-Carotene has immune modulatory effect on animals and humans (Garewal et al., 1992).

Macerated oils, also called infusion oils, are carrier oils used to remove the therapeutic properties of a particular plant or plant. The use of infusion oils in any skin care preparation is highly therapeutic as it contains both the nutritional properties of the carrier oil and the plants (Impa, 2018). The maceration process ensures the passage of substances soluble in oil and alcohol. For this purpose, sunflower oil or olive oil is preferred as carrier oil. By extraction method, only the small molecules are retained while the small molecules in the maceration product are transferred to the fat molecules. Thus, the contents of the plant are maximized. Macerated oil is a super complex containing all substances that can be dissolved in oil if taken as a whole. It is not considered as an active substance. The cost of essential oils is almost 1 in 100 (URL-1, 2019).

There are several studies on the effect of macerated oils obtained from plants on fish (Yüngül et al., 2014; Altınterim et al., 2018a; Altınterim, 2019; Altınterim and Aksu, 2019). Studies with tomatoes and carrots have never been found. Therefore, in this study, it is aimed to investigate the effect of tomato and carrot oils obtained by macera method on rainbow trout.

\section{MATERIAL AND METHODS}

In this study, a total 90 rainbow trout were divided into 3 groups each group consisted of two tanks (two replicates) and each tank contained 15 rainbow trout (O. mykiss) with an average weight of $35.88 \pm 1.97 \mathrm{~g}$. was used. Prior to the start of the experiments, the fish were subjected to acclimation for two weeks. In intensive storage groups, 40 fish were stored in $472 \mathrm{~L}$ tanks and 10 fish in the same volume tanks in the control group. The tomato (Lycopersicon esculentum) and carrot (Daucus carota) oil were waited in sunflower oil (1/10) for 10 days to obtain macerated oil. These oils were added to trout feed in $2 \%$ ratio (The content of commercial feed is given in Table 1). During the study, fish were fed twice a day for 21 days. Fish were fed on an average of $2 \%$ of the weight of fish.

Table 1. Content of Gümüşdoğa brand trout feed

\begin{tabular}{ll}
\hline Content & Quantity \\
\hline Raw Protein & Min 45\% \\
Raw Fat & Min 20\% \\
Raw Cellulose & Max 3\% \\
Raw Ash & Max 12\% \\
Moisture & Max 12\% \\
Phosphorus & Min 1.5\% \\
Calcium & Min-Max 1-2\% \\
Lysine & Min 1.6\% \\
METH+CYST & Min $1.6 \%$ \\
Omega 3 & $1 \%$ \\
Omega 6 & $1.5 \%$ \\
EPA+DHA & $5 \%$ \\
Vitamin A & $5000 \mathrm{IU} / \mathrm{kg}$ \\
Vitamin D3 & $30 \mathrm{IU} / \mathrm{kg}$ \\
Vitamin E & $30 \mathrm{mg} / \mathrm{kg}$ \\
Vitamin C & $125 \mathrm{mg} / \mathrm{kg}$ \\
Metabolic Energy & $4000 \mathrm{Kcal} / \mathrm{kg}$ \\
Digesible Energy & $4350 \mathrm{Kcal} / \mathrm{kg}$ \\
\hline
\end{tabular}

After 21 days, the fish were anesthetized with the anesthetic agent (Benzocaine $30 \mathrm{mg} / \mathrm{L}$ ) for blood collection. Trials were conducted in accordance with ethical rules (Inonu University, Faculty of Medicine, Ethics Committee of Experimental Animals, Protocol No: 2017/A-24). Blood samples were taken from the tail veins of fish with vacutainerand transferred to the tubes with EDTA. Full blood count was also carried out on the same day from EDTA blood samples by spectrophotometrically using nitroblue tetrazolium (NBT) activity (total oxidative radical production of neutrophils) and PROCAN PE6800VET fully automated hematology analyzer. That analyzer was capable of detecting nuclei cells of animals blood such as fish, reptile, chicken etc. White blood cell (WBC) counts, lymphocyte (LYM), monocyte (MID), granulocyte (GRAN), the red blood cell (RBC), the haemoglobin concentration (HGB), the haematocrit (HCT) level, the mean corpuscular volume (MCV), the mean corpuscular haemoglobin $(\mathrm{MCH})$, the mean 
corpuscular haemoglobin concentration (MCHC). and, red cell distribution width standard deviation (RDW-CD), red cell distribution width coefficient of variation (RDW-SD), platelet (PLT), mean platelet volume (MPV), platelet distribution width (PDW), plateletcrit (PCT), platelet large cell ratio (P-LCR) analysed with PROCAN PE-6800VET.

Routine statistical methods and SPSS statistical program were used to evaluate the obtained data. Evaluation of the obtained hematological data One way anova test was performed in $p<0.05$ confidence interval.

\section{RESULTS AND DISCUSSION}

There was a decrease in the lymphocyte (LYM) values of the control groups due to stress, whereas in the carrot group there was a significant increase in both tomato and carrot groups compared to the control groups. Reduction in the number of erythrocytes (RBC) in the stress group returned to normal levels in carrot and tomato applied stress groups. A similar pattern was observed in the levels of hematocrit (HCT), hemoglobin (HGB) and erythrocyte hemoglobin in groups such as erythrocyte levels. Nitro blue tetrazolium (NBT) levels, which are indicative of the non-specific immune system, were higher in the carrot group, however, there was a significant increase in the tomato group compared to the control group (Table 2 ). Although not statistically significant, leucocyte levels of carrot and tomato groups were higher than control groups. In particular, the increase in monocyte and granulocyte levels due to stress was observed to decrease in carrot and tomato oils. The mean corpuscular volume (MCV) values of the applicationgroups increased compared to the control groups, whereas the mean corpuscular haemoglobin concentration (MCHC) values decreased in thecontrol group. In the red cell distribution (RDW) values, increases in application groups were determined depending on stress (Table 3).

In our study, both macerated carrot oil group and macerated tomato oil group were found to have increased LYM, RBC, HGB, HCT, MCH and NBT values compared to the control group. Especially carrot oil group had higher values than tomato group. Increased stress suppressed both the immune system and the erythropoiesis. Both of the experimental groups were found to have negative feedback.

Leucocyte level of fish was an indicator in immune system of fish. Decrease in WBC counts after exposure to density stocking may indicate an immune suppressive effect. We have demonstrated that the WBC level was significantly lower than control stress group that were exposed to stres. However, in the other two groups, especially in carrot oil group, it was determined that WBC level increased despite stress compared to control groups (Amirkolaie et al., 2015).

Table 2. Mean values of blood parameters measured at the end of 21 days feed in according to experimental groups $(\mathrm{p}<0.05)$

\begin{tabular}{lllll}
\hline Blood parameters & Control & Control stress & Carrot stress & Tomato stress \\
\hline LYM $\left(10^{3} \mu \mathrm{L}^{-1}\right)$ & $38.6 \pm 10.34^{\mathrm{a}}$ & $34.7 \pm 4.10^{\mathrm{a}}$ & $54.2 \pm 6.65^{\mathrm{b}}$ & $43.1 \pm 6.81^{\mathrm{ab}}$ \\
RBC $\left(10^{6} \mu \mathrm{L}^{-1}\right)$ & $2.89 \pm 0.42^{\mathrm{a}}$ & $1.73 \pm 0.54^{\mathrm{b}}$ & $2.97 \pm 0.43^{\mathrm{a}}$ & $1.87 \pm 0.31^{\mathrm{b}}$ \\
HGB $(\mathrm{g} / 100 \mathrm{ml})$ & $6.96 \pm 2.42^{\mathrm{a}}$ & $7.15 \pm 3.61^{\mathrm{a}}$ & $13.12 \pm 1.09^{\mathrm{b}}$ & $8.76 \pm 1.76^{\mathrm{a}}$ \\
HCT $(\%)$ & $24.06 \pm 5.77^{\mathrm{ab}}$ & $16.2 \pm 8.63^{\mathrm{a}}$ & $32.55 \pm 3.35^{\mathrm{b}}$ & $19.82 \pm 3.87^{\mathrm{a}}$ \\
MCH $(\mathrm{pg})$ & $23.76 \pm 6.24^{\mathrm{a}}$ & $39.85 \pm 8.27^{\mathrm{b}}$ & $44.55 \pm 4.53^{\mathrm{b}}$ & $46.40 \pm 3.00^{\mathrm{b}}$ \\
PLT $\left(10^{3} \mu \mathrm{L}^{-1}\right)$ & $1538.66 \pm 262.40^{\mathrm{a}}$ & $464,50 \pm 125.50^{\mathrm{b}}$ & $164.75 \pm 9.85^{\mathrm{bc}}$ & $26.80 \pm 8.41^{\mathrm{c}}$ \\
MPV (fL) & $10.90 \pm 0.93^{\mathrm{a}}$ & $8.00 \pm 0.40^{\mathrm{b}}$ & $11.72 \pm 0.08^{\mathrm{a}}$ & $13.90 \pm 0.51^{\mathrm{c}}$ \\
PDW $(\%)$ & $14.76 \pm 2.57^{\mathrm{ab}}$ & $8.20 \pm 0.00^{\mathrm{a}}$ & $20.77 \pm 0.64^{\mathrm{b}}$ & $17.72 \pm 2.49^{\mathrm{b}}$ \\
PCT $(\%)$ & $1.62 \pm 0.16^{\mathrm{a}}$ & $0.74 \pm 0.46^{\mathrm{b}}$ & $0.19 \pm 0.01^{\mathrm{c}}$ & $0.34 \pm 0.01^{\mathrm{c}}$ \\
P-LCR (\%) & $26.26 \pm 4.86^{\mathrm{a}}$ & $11.25 \pm 2.65^{\mathrm{b}}$ & $32.22 \pm 0.59^{\mathrm{a}}$ & $50.50 \pm 2.63^{\mathrm{c}}$ \\
NBT(Neutrophil & $0.54 \pm 0.16^{\mathrm{a}}$ & $0.72 \pm 0.03^{\mathrm{ab}}$ & $0.94 \pm 0.15^{\mathrm{b}}$ & $0.83 \pm 0.13^{\mathrm{b}}$ \\
counts) & & & \\
\hline
\end{tabular}

\#Lymphocyte (LYM), red blood cell (RBC), haemoglobin concentration (HGB), haematocrit (HCT) level, the mean corpuscular haemoglobin (MCH), platelet (PLT), mean platelet volume (MPV), platelet distribution width (PDW), plateletcrit (PCT), platelet large cell ratio (P-LCR), Nitroblue tetrazolium (NBT). 
Table 3. The values of other blood parameters (WBC, MID, GRAN, MCV, MCHC, RDW-SD, RDW-CV) according to experimental groups (Means \pm Standard Error).

\begin{tabular}{lccccccc}
\hline Groups & $\begin{array}{c}\text { WBC } \\
\left(10^{3} \mu \mathrm{L}^{-1}\right)\end{array}$ & $\begin{array}{c}\text { MID } \\
\left(10^{3} \mu \mathrm{L}^{-1}\right)\end{array}$ & $\begin{array}{c}\text { GRAN } \\
\left(10^{3} \mu \mathrm{L}^{-1}\right)\end{array}$ & $\begin{array}{c}\text { MCV } \\
(\mathrm{fL})\end{array}$ & $\begin{array}{c}\text { MCHC } \\
(\%)\end{array}$ & $\begin{array}{c}\text { RDW- } \\
\text { SD (fL) }\end{array}$ & $\begin{array}{c}\text { RDW- } \\
\mathrm{CV}(\%)\end{array}$ \\
\hline Control & $41.73 \pm 6.20$ & $2.00 \pm 0.26$ & $1.06 \pm 0.23$ & $84.10 \pm 11.47$ & $31.03 \pm 9.85$ & $65.66 \pm 6.30$ & $17.33 \pm 4.08$ \\
\hline Control stress & $39.45 \pm 5.25$ & $2.65 \pm 1.05$ & $2.10 \pm 1.30$ & $90.30 \pm 15.00$ & $44.45 \pm 1.05$ & $50.20 \pm 5.60$ & $11.75 \pm 0.55$ \\
\hline Carrot stress & $58.0 \pm 3.58$ & $2.60 \pm 0.18$ & $1.15 \pm 0.09$ & $110.20 \pm 2.42$ & $40.40 \pm 1.25$ & $59.92 \pm 4.04$ & $11.65 \pm 1.05$ \\
\hline Tomato stress & $46.16 \pm 3.34$ & $2.08 \pm 0.59$ & $0.94 \pm 0.10$ & $105.40 \pm 2.80$ & $44.10 \pm 0.30$ & $69.90 \pm 3.98$ & $14.18 \pm 1.09$ \\
\hline $\begin{array}{l}\text { \#White blood cell (WBC) counts, monocyte (MID), granulocyte (GRAN), the mean corpuscular volume (MCV), the } \\
\text { mean corpuscular haemoglobin (MCH), the mean corpuscular haemoglobin concentration (MCHC) and red cell } \\
\text { distribution width standard deviation (RDW-CD), red cell distribution width coefficient of variation (RDW-SD) }\end{array}$
\end{tabular}

Benfey and Biron (2000) reported that the level of WBC was decreased due to the stress of Oncorhynchus mykiss and Salvelinus fontinalis. In addition, increased stress reduces the number of lymphocytes in the bloodstream and causes them to disappear. In our study, the number of WBC and LYM decreased with stress. However, WBC and LYM values were found to increase in the table carrot and tomato oil groups.

The results of Ural (2013)'s study revealed that $\mathrm{RBC}, \mathrm{HCT}, \mathrm{HGB}$ and $\mathrm{MCH}$ values were increased in Lycopene trial similar to our study and lymphocyte (LYM) parameter of specific defense system and erythropoiesis decreased in stress control groups due to high stocking density.

In Talebi et al. (2013)'s study, they used a red carotenoid containing red pepper. $\mathrm{RBC}, \mathrm{Hb}$, Hct ratios were significantly higher compared to the control group. In our study, it was paralleled with the findings of macerated carrot oil containing the common carotenoids.

The increasing level of NBT indicates that the immune system of the fish was activated that the body of fish is protected itself against possible infections due to increasing density and decreasing oxygen level. The important component of the nonspecific immune system was phagocytic activity (Blazer, 1991; Sharp and Secombes, 1993; Sahan et al., 2015).

The increase in the level of NBT, which was an indicator of non-specific defense mechanism in the all groups of our study. In our study, the phagocytic activity increased significantly in groups of macerated carrot and tomato oil. Some paramaters of the innate immunitywere significantly lower in the stressgroups.

All of the values of the stress control group decreased compared to all of the values of the normal control group. The NBT activity of the carrot group was higher than the tomato group. In other study, it was explained that carotenoids stimulated the phagocytic activity of $O$. mykiss (Amar et al., 2004).

According to results of our study, it was determined that both the macerated carrot oil and the macerated tomato oil increased the phagocytosis capacity by stimulating the granulocytes of the fish against the adverse conditions caused by intensive storage. In addition, it was determined that macerated oils were helped to protect homeostasis and they were stimulated blood production and provided maximum oxygenation of blood against low oxygen levels. Jha et al. (2007) reported that increased leucocyte counts and respiratory burst activities of rainbow trout with fed a diet supplemented.

Some investigations reported that the positive role of carotenoids against oxidative stress on rainbow trout. We found to increase with phagocytic activities in fish fed $\beta$-carotene like in Amar (2004)'s and Sakai (1999)'s previous studies (Burton and Ingold, 1984; Sakai, 1991).

Treatments in other study, the astaxanthin was found to be more ineffective than the plant pigment, although they involved in equal amounts of carotenoids (Ural, 2013). Carotene was revealed to be an efficient antioxidant under low oxygen (Burton and Ingold, 1984). 
Altınterim et al. (2018b) investigated the effects of masere oils obtained from 8 different plants on densely stocked trout. Granulocyte cell level (GRAN), hematocrit (HCT) value and platelet (PLT) values of the highest levels in poppy oil It was determined $(p<0.05)$. Ginger oil on white blood while providing maximum increase in cells (WBC), lymphocyte (LYM) cells were the highest in this group levels $(p<0.05)$. The amount of hemoglobin and mean volume (MCV) and mean of erythrocytes platelet volume (MPV) values in ginger. It was determined that the highest level in the group $(p<0.05)$. Erythrocyte in turmeric oil group cells $(\mathrm{RBC})$ is the maximum level $(\mathrm{p}<0.05)$. Sweet basil oil application highest percentage of monocytes (\% MID) It was determined that $(p<0.05)$. As seen, the effects of different plants on different parameters of blood values of fish were also different. In this study, the effects of carrot and tomato oils on blood parameters were found to be different. However, the increase in carrot group values was higher than tomato group.

\section{CONCLUSION}

Both tomato and carrot macerated oils have developed protective properties against stress. However, the increase in the values of carrot masere group was higher than tomato group. It is recommended to use $2 \%$ of macerated oils which have low production cost in fish farming.

\section{REFERENCES}

Altınterim, B., Öztürk, E., Kutluyer, F., Aksu, Ö., 2018a. Effects of green tea (Camellia sinensis) oil on feed utilization and hametological parameters of rainbow trout (Oncorhynchus mykiss). Atatürk University Journal of Veterinary Sciences, 13(2):159-164.

Altınterim, B., Kutluyer, F., Aksu, Ö., 2018b. Effects of different plant oils having different Oxygen Radical Absorbance Capacity (ORAC) on hematological parameters of rainbow trout (Oncorhynchus mykiss) at high stocking density. Atatürk University Journal of Veterinary Sciences, 13(1):63-69.

Altınterim, B., Aksu, Ö., 2019. Effects of oils of macerated garlic (Allium sativum Limne) and macerated Tunceli garlic (Allium tuncelianum Kollman) on some hematological parameters and NBT (Nitroblue Tetrazolium) levels of rainbow trout (Oncorhynchus mykiss W.) at high stocking density.
Journal of Ballkesir University Instituteos Science and Technology, 21(2):716-723.

Altinterim, B., 2019. Influence of macerated fenugreek (Trigonella foenum graecum) oil added to trout feed at the different rates on the Feed Conversion Rate (FCR), body length, blood parameters and Nitroblue Tetrazolium (NBT) values of rainbow trout (Oncorhynchus mykiss Wal). Cellular and Molecular Biology, 65(3):89-93.

Amar, E.C., Kiron, V., Satoh, S., Watanabe, T., 2004. Enhancement of innate immunity in rainbow trout (Oncorhynchus mykiss Walbaum) associated with dietary intake of carotenoids from natural products. Fish \& Shellfish Immunology, 16:527-537.

Amirkolaie, A.K., Dadashi, F., Ouraji, H., Khalili, K.J., 2015. The potential of tomato pomace as a feed ingredient in common carp (Cyprinus carpio L.) diet. Journal of Animal and Feed Sciences, 24:153-159.

Aust, O., Ale-Agha, N., Zhang, L., Wollersen, H., Sies, H., Stahl, W., 2003. Lycopene oxidation product enhances gap junctional communication. Food and Chemical Toxicology, 41:1399-1407.

Beecher, G.R., 1998. Nutrient content of tomatoes and tomato products. Proceedings of the Society for Experimental Biology and Medicine, 218(2):98-100.

Benfey, T.J., Biron, M., 2000. Acute stress response in triploid rainbow trout (Oncorhynchus mykiss) and brook trout (Salvelinus fontinalis). Aquaculture, 184(1-2):167-176.

Blazer, V.S., 1991. Piscine macrophages function and nutritional influences: a review. Journal of Aquatic Animal Health, 3:77-86.

Braun, N., De-Lima, R.L., Baldisserotto, B., Dafre, A.L., De-Oliveira Nuñer, A.P., 2010. Growth, biochemical and physiological responses of Salminus brasiliensis with different stocking densities and handling. Aquaculture, 301:22-30.

Burton, G.W.,I ngold, K.U., 1984. Beta-carotene: an unusual type of lipid antioxidant. Science, 224(4649):569.

Di Mascio, P., Kaiser, S., Sies, H., 1989. Lycopene as the most efficient biological carotenoid singlet oxygen quencher. Archives of Biochemistry and Biophysics, 274:532-538.

Garewal, H.S., Ampel, N.M., Watson, R.R., Prabhala, R.H., Dols, C.L., 1992. A preliminary trial of betacarotene in subjects infected with the human immunodeficiency virus. Journal of Nutrition, 122:728-732.

Giovannucci, E.,1999. Tomatoes, tomato-based products, lycopene, and cancer: review of the epidemiologic literature. Journal of the National Cancer Institute, 91:317-31. 
Gupta, S.K., Jha, A.K., Pal, A.K., Venkateshwarlu, G., 2007. Use of natural carotenoids for pigmentation in fishes. Natural Product Radiance, 6(1)46-49.

İmpa, S., 2018. Healing herbs: learn how to make macerated oils. https://freakofnatural.com/healingherbs-learn-how-to-make-macerated-oils/ 28 Aralık 2019.

Jha, A.K., Pal, A.K., Sahu, N.P., Kumar, S., Mukherjee, S.C., 2007. Haemato-immunological responses to dietary yeast RNA, $\omega-3$ fatty acid and $\beta$-carotene in Catla catla juveniles. Fish \& Shellfish Immunology, 23:917-927.

Kobayashi, T., Iijima, K., Mitamura, T., Torızuka, K., Cyong, J.C., Nagasawa, H., 1996. Effects of lycopene, a carotenoid, on intrathymic $\mathrm{T}$ cell differentiation and peripheral CD4/CD8 ratio in a high mammary tumors train of SHN retired mice. Anticancer Drugs, 7(195):8.

Meydani, S.N., Wu, D., Santos, M.S., Hayek, M.G., 1995. Antioxidants and immune response in aged persons: overview of present evidence. The American Journal of Clinical Nutrition, 62:14621476.

Palozza, P., Catalano, A., Simone, R., Cittadini, A., 2012. Lycopene as a guardian of redox signalling. Acta Biochimica Polonica, 59:21-25.

Rao, A.V., Agarwal, S., 1999. Role of lycopene as antioxidant carotenoid in the prevention of chronic diseases: a review. Nutrition Research, 19:305-323.

Raym, M.R.,Rao, L.G., 2006. Lycopene. Advances in Food and Nutrition Research, 51:99-164.

Sahan, A., Tasbozan, O., Aydın, F., Ozutok, S., Erbas, C., Duman, S., Uslu, L., Ozcan, F., 2015. Determination of some haematological and nonspecific immune parameters in Nile tilapia (Oreochromis niloticus L., 1758) fed with spirulina (Spirulina platensis) added diets. Journal of Aquaculture Engineering and Fisheries Research, 1(3):133-139.

Sakai, M., 1991. Current status of fish immunostimulants. Aquaculture, 172:63-92.

Sharp, G.J.E., Secombes, C.J., 1993. The role of reactive oxygen species in the killing of the bacterial fish pathogen Aeromonas salmonicida by rainbow trout macrophages. Fish \& Shellfish Immunology, 3(2):119-129.

Talebi, M., Khara, H., Zoriehzahra, J., Ghobadi, S., Khodabandelo, A., Mirrasooli, E., 2013. Study on effect of red bell pepper on growth, pigmentation and blood factors of rainbow trout (Oncorhynchus mykiss). World Journal of Zoology, 8(1):17-23.

Ural, M.S., 2013. Chlorpyrifos-induced changes in oxidant/antioxidant status and haematological parameters of Cyprinus carpio carpio: Ameliorative effect of lycopene. Chemosphere, 90:2059-2064.
URL-1, 2019. https://formulabotanica.com/how-to-makemacerated-oils/_How to make macerated oils. 28 Aralık 2019.

Wozniake, M., 1996. The role of carotenoids in fish. Protectio Aquarum Et Piscatoria, 22:65-75.

Yüngül, M., Altınterim, B., Dörücü, M., 2014. The investigation of antibacterial effects of macerated and distilled oil obtained from endemic plants against Yersinia ruckeri with aromatogram method. Bilim ve Gençlik Dergisi, 2(2):1-7. 